Warszawa

\title{
Zdolności wojskowe Unii Europejskiej. Perspektywy grup bojowych
}

Rozwój europejskich zdolności wojskowych był jednym z najbardziej kontrowersyjnych tematów, który towarzyszył narodzinom Unii Europejskiej i nad którym debatowano ponad dwie dekady. Zresztą, dotychczas nie wypracowano jednolitego stanowiska wobec użycia sił wojskowych i mało prawdopodobne jest, ażeby Państwa Członkowskie Unii Europejskiej osiagnęły w tej sprawie jednomyślność. Niemniej jednak sprawom tym poświęcono tysiące publikacji, kilkaset deklaracji politycznych i kilka zobowiązań traktatowych. Podsumowując pierwszą dekadę przynależności Polski do UE, warto przyjrzeć się dorobkowi w dziedzinie umownie nazywanej ,polityką obronną", z uwzględnieniem potencjału i zdolności.

Zarówno ze względów formalnych, jak też rzeczowych w rozwoju tej polityki można wyodrębnić trzy zasadnicze etapy:

1) Europejskiej Tożsamości Bezpieczeństwa i Obrony, to lata 1993-1999 (Zięba, 2000). Na tym etapie, zgodnie z zapisem Traktatu z Maastricht, Unia mogła korzystać ze zdolności wojskowych Unii Zachodnioeuropejskiej, która w Deklaracji z Petersbergu określiła trzy typy misji, które mieściły się w formule reagowania kryzysowego: humanitarne, utrzymania pokoju, przywracania pokoju (Kuźniar, 2005);

2) Europejskiej Polityki Bezpieczeństwa i Obrony został zapoczątkowany 4 czerwca 1999 r. Deklaracją Rady Europejskiej przyjętej w Kolonii, a zamknięty 1 grudnia 2009 r.;

3) Wspólnej Polityki Bezpieczeństwa i Obrony, realizowanej od 2009 r. na podstawie zapisów Traktatu lizbońskiego (Ciupiński, 2013, s. 125-160).

W pierwszym etapie, z punktu widzenia zdolności wojskowych, wizytówką europejskiej obrony był EUROKORPUS, utworzony z inicjatywy Francji i Niemiec w 1993 r., który zdolność operacyjną uzyskał w 1995 r. Był on podwójnie podporządkowany: w NATO był zobowiązany do działań obronnych na podstawie art. 5 Traktatu waszyngtońskiego, a w ramach UZE przewidywano wykorzystanie go do realizacji misji typu petersberskiego. Państwa śródziemnomorskie powołały do życia wyspecjalizowane wojska lądowe - EUROFORU oraz siły morskie - EUROMARFORU.

Bilans praktycznych rezultatów działań realizowanych przez Unię Zachodnioeuropejską w sferze Europejskiej Tożsamości Bezpieczeństwa i Obrony był bardziej niż skromny. Trudno też wskazać udaną misję czy operację przeprowadzoną w latach dziewięćdziesiątych, według kryteriów wyrażonych w Deklaracji z Petersbergu. Dlatego też, można zrozumieć tendencję gremiów Unii Europejskiej do przejęcia pełnej odpowiedzialności za system reagowania kryzysowego, włączając do niego także 
komponenty wojskowe. 4 grudnia 1998 r., odbył się francusko-brytyjski szczyt w Saint Malo, podczas którego przywódcy Jacques Chirac i Tony Blair uzgodnili Deklaracje o europejskiej obronie, w której oświadczyli między innymi, że UE powinna rozwijać „samodzielne zdolności wojskowe” (Integracja, 2002, s. 82-97). Widziano w tym wydarzeniu nawiązanie do tradycji współpracy wojskowej francusko-brytyjskiej podczas dwóch wojen światowych. Dwie europejskie potęgi zgodziły się w kilku zasadniczych punktach:

1) Unia Europejska musi mieć możliwość odgrywania głównej roli na scenie międzynarodowej. Ażeby to osiągnąć, należy szybko i w pełni wdrożyć postanowienia Traktatu amsterdamskiego dotyczące WPZiB. Oznaczało to przejęcie odpowiedzialności przez Radę Europejską za stopniowy rozwój polityki wspólnej obrony, w ramach WPZiB. Zapewniano, że decyzje podejmowane będą z poszanowaniem suwerenności, na zasadach współpracy międzyrządowej;

2) Unia Europejska winna mieć autonomiczną zdolność do działań, w międzynarodowych kryzysach, dysponując siłą wojskową i możliwością jej użycia. Pozostają w mocy zobowiązania państw do wspólnej obrony z tytułu artykułu 5 Traktatu waszyngtońskiego oraz artykułu V Traktatu brukselskiego. Działania, w zakresie wspólnej obrony, Europejczycy realizować będą w instytucjonalnych ramach Unii Europejskiej, a więc poprzez Radę Europejską, Radę UE do spraw Ogólnych oraz spotkania ministrów obrony;

3) Unia Europejska winna dysponować zdolnością oceny sytuacji, dostępem do źródeł informacji, zdolnością planowania strategicznego i prawem sięgania do środków wojskowych NATO, nawet w sytuacjach, gdy cały Sojusz nie będzie uczestniczył w działaniach przez UE podejmowanych;

4) Unia Europejska potrzebuje nowoczesnych sił zbrojnych, opartych na konkurencyjnej i silnej bazie w przemyśle i technologii obronnej, zdolnych przeciwstawić się nowym zagrożeniom.

Przełamanie dotychczasowej nieufności francusko-brytyjskiej stworzyło warunki do rozpoczęcia drugiego etapu w rozwoju europejskich zdolności reagowania kryzysowego, szczególnie w odniesieniu do wojskowych komponentów tych zdolności. Od 1 maja 1999 r. obowiązywał Traktat o UE z Amsterdamu, który dawał podstawy prawne do przejęcia przez Unię Europejską struktur i zasobów obronnych Unii Zachodnioeuropejskiej. Szczegółowe postanowienia w tej sprawie podjęto na posiedzeniu Rady Europejskiej 4 czerwca 1999 r. w Kolonii (Ciupiński, 2013, s. 66-73). Z kolei, na spotkaniu w Helsinkach sformułowano Europejski Cel Zasadniczy/Operacyjny zapowiadając utworzenie do końca 2003 r. Europejskiego Korpusu Szybkiego Reagowania. Przy Radzie UE miało powstać kilka organów politycznych i wojskowych. Miały to być tymczasowe: Komitet Polityczny i Bezpieczeństwa, Komitet Wojskowy UE oraz Sztab Wojskowy UE (Słomczyńska, 2007, s. 202; Barcik, 2008, s. 253-257).

Z punktu widzenia rozwoju samodzielnych zdolności wojskowych postanowiono zorganizować do 2003 r. Europejski Korpus Szybkiego Reagowania, na który mogło się składać około 15 brygad, o ogólnej liczebności 50-60 tys. żołnierzy. Jednostki te powinny być zdolne do działań, w rejonach kryzysu na odległość do 6 tys. km. Z chwilą uzyskania zdolności operacyjnych, korpus miał być gotowy do podjęcia działań opanowania kryzysów, w ciągu 60 dni od przyjęcia decyzji politycznej (Zięba, 2005, s. 47-99). 
Postanowiono, że ma on być samowystarczalny, pod każdym względem: dowodzenia, kontroli, wywiadu, logistyki, a także będzie dysponować jednostkami wsparcia. Korpus reagowania kryzysowego miał zawierać nie tylko komponent w postaci sił lądowych, ale także lotnictwo i marynarkę. Program okazał się zbyt ambitny, ale usiłowano go zrealizować między innymi poprzez, wykrycie braków i słabości, a następnie sformułowanie Planu działań w zakresie poprawy zdolności. Sytuacja była dosyć wstydliwa, ponieważ przy nominalnym stanie sił zbrojnych państw członkowskich ok. $2 \mathrm{mln}$ żołnierzy zapowiadanego korpusu nie udało się sformować. Owszem, na konferencjach ministrów obrony zadeklarowano kontyngenty żołnierzy i broni; pierwsze katalogi obejmowały ogółem ok. 100 tys. ludzi, 400 samolotów i 100 okrętów (Dumoulin, Mathieu, Sarlet, 2003, s. 262-263). Jednak, powątpiewano w możliwości ekspedycyjne i operacyjne tych sił, a także kwestionowano zasadność tworzenia dużej, 60-tysięcznej formacji wojskowej. Dlatego też, chociaż takiej formacji nie zbudowano, oficjalnie ogłoszono, że Europejski Cel Zasadniczy/Operacyjny został osiąnnięty i zapowiedziano dalsze doskonalenie i wzbogacanie posiadanego potencjału.

\section{Europejski Cel Zasadniczy/Operacyjny - 2010}

Działania reformatorskie w sferze obronnej przyniosły kilka pozytywnych rezultatów. Przede wszystkim doszło do normalizacji stosunków i zawiązania współpracy pomiędzy Unią Europejską i NATO. W pakiecie kilkunastu porozumień, zwanych „Berlin plus" sojusz zobowiązywał się między innymi do udostępnienia zdolności planistycznych, danych wywiadu, łańcucha dowodzenia, a także transportu strategicznego. Korzystano też z teoretycznego i praktycznego dorobku w zakresie reagowania kryzysowego. Inspiracją dla reformatorów systemu bezpieczeństwa UE były decyzje podjęte na szczycie sojuszu, w Pradze 21 i 22 listopada 2002 r. Jednym z elementów mogących podnieść zdolności obronne miały być Siły Odpowiedzi NATO - SONATO, wyposażone w nowoczesne uzbrojenie i zdolne do szybkiej dyslokacji w rejon kryzysu ,wszędzie, gdzie zajdzie potrzeba". W założeniach, powinny one mieć charakter uniwersalny i w razie konieczności działać jako siły połączone (wojska lądowe, lotnictwo, marynarka wojenna).

Rada ds. Ogólnych i Stosunków Zewnętrznych na posiedzeniu w dniu 19 listopada 2002 r. wyraziła postulat skrócenia czasu przygotowania reagowania kryzysowego, w sytuacjach nagłych i w związku z tym zaleciła rozpatrzenie możliwości wykorzystania, do interwencji zewnętrznych, unijnych ugrupowań taktycznych (Haine, 2003, s. 150-158). Uznano, że UE powinna dysponować zdolnością samodzielnego przemieszczania sił reagowania kryzysowego w ciagu 15 dni, w celu opanowania kryzysu. Eksperci brytyjscy i francuscy wspólnie przygotowali wstępne założenia i podczas francusko-brytyjskiego szczytu w Londynie, 24 listopada 2003 r., uzgodniono projekt doskonalenia europejskich sił szybkiego reagowania. Projekt grup bojowych został wkomponowany do planu o szerszym charakterze i opublikowany w dokumencie pt. „Europejski Cel Operacyjny 2010”. Został on zaakceptowany przez Radę ds. Ogólnych i Stosunków Zewnętrznych 17 maja 2004 r. i przyjęty przez Radę Europejską 17-18 czerwca 2004 roku. Nowy cel nawiązywał do założeń Europejskiej Strategii 
Bezpieczeństwa uwzględniając ewolucję środowiska strategicznego oraz rozwój technologiczny, a także wnioski płynące z dotychczasowych operacji przeprowadzonych przez Unię Europejską. W dokumencie potwierdzono tezę, że Unia Europejska jest globalnym aktorem, gotowym dzielić odpowiedzialność za światowe bezpieczeństwo, a w związku z tym ma posiadać militarne i pozamilitarne zdolności przeciwdziałania nowym zagrożeniom. Myślą przewodnią nowego celu operacyjnego była potrzeba przeglądu zdolności armii europejskich, a szczególnie ich szybkiej reakcji, na zaistniałe kryzysy. Państwa członkowskie powinny, na zasadzie dobrowolności, samodzielnie reformować swoje siły zbrojne i zwiększać ich możliwości operacyjne, zarówno pod względem technicznym, jak i koncepcyjnym. W dokumencie wystapiono z apelem o rozwój europejskiej kultury strategicznej, która kładłaby nacisk na zwiększenie możliwości i zdolności wojskowych państw członkowskich UE.

W ramach EHG-2010 wyspecyfikowano priorytetowe zadania i dotyczyły one: 1) ukompletowania składów europejskich grup bojowych do 2007 r.; 2) rozbudowy Europejskiego Dowództwa Powietrznych Sił Przerzutowych; dostępności samolotów transportowych, wraz z osłoną lotniczą do 2008 r.; 3) zapewnienia kompatybilności wszystkich rodzajów łączności i sprzętu (naziemnego i kosmicznego), na wszystkich poziomach operacji unijnych; 4) doskonalenia jednolitych wzorców i kryteriów przygotowania i szkolenia sił zadeklarowanych do realizacji Europejskiego Celu Operacyjnego. Punktem wyjścia dla realizacji EHG-2010 były rezultaty prac koncepcyjnych i doświadczeń wyniesionych z pierwszych operacji przeprowadzonych w $2003 \mathrm{r}$. W rezultacie prac grupy nr VIII Konwentu Europejskiego oraz przyjęcia Strategii Bezpieczeństwa Unii Europejskiej rozszerzono zakres zadań i misji.

Rozszerzono tzw. misje petersberskie plus, które obejmowały: 1) połączone operacje rozbrojeniowe (Joint desarmament operations - JDO); 2) wsparcie państw trzecich $\mathrm{w}$ walce z terroryzmem, operacje wspierające reformy sektora bezpieczeństwa (Security Sector Reform). Zarówno pierwotne, czyli traktatowe misje reagowania kryzysowego, jak i te rozszerzone były sformułowane bardzo ogólnie. Dopiero w toku dalszych prac, podejmowano próby określenia charakteru przewidywanych działań i w rezultacie wskazano pięć najbardziej prawdopodobnych scenariuszy reagowania wojskowego Unii Europejskiej: a) rozdzielenie stron walczących; b) zapobieganie konfliktowi; 3) stabilizacja, odbudowa i doradztwo wojskowe; 4) ewakuacja personelu operacji $\mathrm{z}$ niebezpiecznego terenu (non-permissive environment); 5) wsparcie wojskowe pomocy humanitarnej.

Przez kilka lat następowało doskonalenie metodyki dopracowania tych scenariuszy i ich korelacja $z$ bardziej konkretnymi zadaniami, czyli ukierunkowanymi operacjami wojskowymi, które posłużyły do określenia ram planowania. Następnym etapem było opracowanie szczegółowego wykazu niezbędnych zdolności, konfrontowanych z realnymi możliwościami jednostek, zadeklarowanych przez państwa członkowskie UE. W ten sposób można było określić „katalog potrzeb” dotyczący typów jednostek, ich uzbrojenia i wyposażenia, a także rodzaju wyszkolenia typowego i specjalistycznego (EU Battlegroups, 2007; Simón, 2010, s. 21).

Katalog potrzeb był adresowany do państw członkowskich, w formie kwestionariusza realizacyjnego celu operacyjnego. Sugerowano, ażeby w składaniu ofert kierowano się tym kwestionariuszem. Proponowano także ujednolicenie metod i kryteriów oceny 
własnych możliwości, udostępniając odpowiedni „podręcznik”. Cały ten proces służył wypracowaniu adekwatnego Katalogu Sit Unii Europejskiej. 19 listopada 2007 r. Rada UE zaakceptowała Katalog Postęu, w zakresie realizacji Europejskiego Celu Operacyjnego - 2010. Rada uznała, że UE w 2010 r. osiagnie możliwość prowadzenia operacji WPBiO, w całym spektrum misji traktatowych i instytucje odpowiedzialne za WPBiO są zdolne do planowania i realizacji zadań w regionach objętych kryzysami. Stwierdzono jednocześnie występowanie licznych braków i opóźnień w sferze pozyskiwania zdolności wojskowych (Background Note, 2008). Do działań w zakresie ich wyeliminowania postanowiono włączyć działającą od 2004 r. Europejską Agencję Obrony (EDA). Proces przygotowania i certyfikacji GB-1500 dokonywał się według instrukcji (przewodników), opracowanych w Sztabie Wojskowym Unii Europejskiej. Wyodrębniono dziewięć kryteriów, które posłużyły do wypracowania rekomendacji i standardów: 1) dostępność, 2) wszechstronność, 3) samowystarczalność, 4) zdolność do przemieszczenia, 5) gotowość, 6) komunikacja, 7) zdolność do przetrwania, 8) ochrona medyczna, 9) interoperacyjność.

\section{Doświadczenia organizacyjne i szkoleniowe GB-1500}

22 października 2004 r. na specjalnej konferencji zdolności wojskowych (Military Capability Commitment Conference), ministrowie obrony państw członkowskich Unii Europejskiej oficjalnie zatwierdzili utworzenie 13 Grup Bojowych (Battle Groups), z udziałem 20 państw. Grupy narodowe zadeklarowały: Francja, Hiszpania, Wielka Brytania, Włochy. Przez kilka najbliższych lat poszczególne państwa, lub grupy państw deklarowały możliwość utworzenia i wykorzystania kolejnych grup i w związku z tym ich ilość oscylowała w przedziale 15-20 jednostek, zdolnych do podjęcia działań w zakresie szybkiego reagowania (Military, 2004, s. 5).

W 2007 r. po osiagnięciu pełnej zdolności operacyjnej GB-1500 miały funkcjonować w następujących układach: 1) Czechy, Słowacja; 2) Francja, Belgia; 3) Wielka Brytania, Holandia; 4) Niemcy, Francja, Bułgaria, Luksemburg, (Hiszpania); 5) Niemcy, Austria, Czechy - grupa wielonarodowa; 7) Polska, Niemcy, Słowacja, Litwa, Łotwa; 8) Niemcy, Holandia, Finlandia; 9) Włochy, Węgry, Słowenia; 10) Włochy, Hiszpania, Grecja, Portugalia (morska grupa bojowa); 10) Finlandia, Szwecja, Norwegia, Estonia; 11) Grecja, Bułgaria, Cypr, Rumunia (bałkańska grupa bojowa); 12) Szwecja, Finlandia, Estonia, Norwegia - nordycka grupa bojowa; 13) Włochy, Rumunia, Turcja.

Państwa członkowskie UE zadeklarowały, w sumie 18 Grup Bojowych. Nie wszystkie spośród nich pomyślnie przeszły proces certyfikacji, co później spowodowało trudności w zapewnieniu pełnej obsady dyżurów (Cloos, 2007, s. 20). Niektóre państwa, oprócz bojowych środków konwencjonalnych zgłosiły możliwość wykorzystania specyficznych zdolności, nazwanych „niszowymi”. Francja zgłosiła możliwość udostępnienia mobilnego stanowiska dowodzenia (structure of a multinational and deployable Force Headquarter); Cypr zaproponował grupę medyczną; Litwa - jednostkę uzdatniania wody; Grecja - morskie centrum koordynacyjne (Konkluzje, 2007). W 2005 r. osiagnięto początkową zdolność operacyjną (Initial Operational Capability 
- IOC). Dyżurów bojowych podjęły się wówczas Wielka Brytania i Francja, a następnie Włochy. Pełną zdolność operacyjną Grupy Bojowe UE osiagnęły od 1 stycznia 2007 roku (Full Operational, 2007). Pierwsze dyżury przyjęły wówczas Francja z Belgią oraz Niemcy, przy współudziale Finlandii oraz Holandii. Jednocześnie uzyskiwano możliwość określenia luk i niedostatków. Początkowo stosowano zasadę pełnienia dyżurów przez dwie grupy bojowe, ale z czasem wystapiły trudności w pozyskiwaniu chętnych do tych dyżurów. W perspektywie najbliższych kilku lat dyżury takie będą pełnić pojedyncze grupy.

Na podstawie praktyki można wyróżnić dwa typy Grup Bojowych UE: „ciężką” i ,lekką”. Pierwszy rodzaj, to oddział złożony z wielu modułów, nie wyłączając pododdziałów wojsk pancernych i wsparcia lotnictwa myśliwskiego, a także z komponentami morskimi. Typ grupy ciężkiej przygotowują np. Niemcy. W tym przypadku stan liczebny Grupy wynosi 3600 ludzi, chociaż w założeniu w rejon kryzysu zostanie przemieszczone, co najwyżej połowa tego składu. Dla odmiany rdzeń grupy belgijsko-francuskiej stanowi batalion zmechanizowany złożony z 800 ludzi, czyli czterech kompanii: 2 belgijskie, 2 francuskie. Razem z innymi komponentami na grupę składa się oddział o liczebności 2200 ludzi: 1450 Belgów i 750 Francuzów oraz niewielki zespół luksemburski zapewniający uzdatnianie wody. W skład grupy wchodzą także: bateria moździerzy $120 \mathrm{~mm}$, siedem helikopterów $A-109$ wraz z załogami, trzy plutony saperów, jeden pluton rozpoznania. Ponadto, niewielkie zespoły: żandarmerii wojskowej, oddziaływania psychologicznego, CIMIC (współpracy cywilno-wojskowej), służba zdrowia, grupa ewakuacyjna (Medevac) oraz zespół informacji (CIS - communication information system). Za dowództwo i sztab odpowiadają Belgowie, a w jego skład wchodzi 180 ludzi.

Tak zwana „grupa francusko-niemiecka” osiagnęła liczebność około 2300 ludzi, ze znaczną przewagą Niemców - 1600, 400 Francuzów i 250 Belgów, 40 Hiszpanów i 20 Luksemburczyków. Zasadniczy trzon grupy stanowi 292. Batalion Bundeswehry (JgBtl292), do którego dołączono jedną francuską kompanię ze 110 pułku piechoty. W skład Grupy wchodzi także mieszany francusko-niemiecki batalion dowodzenia i wsparcia oraz 295. Batalion artylerii oraz pododdział inżynieryjny (France-allemagne, 2010). Elementy wsparcia medycznego dostarczają Belgowie wraz z czterema helikopterami typu Augusta.

Brytyjska grupa bojowa była sformowana $\mathrm{z}$ dwóch batalionów, które zdobywały doświadczenia w Afganistanie i Iraku. W drugiej połowie $2008 \mathrm{r}$. był w Iraku batalion z Królewskiego Pułku Fizylierów (Royal Regiment Fisiliers), który stacjonuje na Cyprze. W 2007 r. był dwukrotnie skierowany do działań w Afganistanie. Drugąjednostką związaną z GB-1500 jest 4. Batalion Strzelców (4e Bataillon „,The Rifles”), który w 2007 roku był operacyjnie zaangażowany w Iraku.

Ciekawych przykładów współpracy w dziedzinie przygotowania grup bojowych dostarczają państwa skandynawskie. Nordyckie ugrupowanie taktyczne zostało utworzone w 2008 r., głównie na bazie sił dostarczonych przez państwo wiodące, którym jest Szwecja (1100 żołnierzy). Finlandia skierowała wsparcie w postaci grupy artylerii, jednostki walki elektronicznej, a także grupy żandarmerii wojskowej, ogółem 200 żołnierzy. Norwegia dostarcza 150 żołnierzy, zaangażowanych głównie w pionie logistycznym, transportu strategicznego. Irlandia skierowała do NBG 80 żołnierzy, nato- 
miast Estonia oddelegowała 50 żołnierzy, z zadaniem ochrony wojsk. Liczebność NBG może wzrosnąć nawet do 3000 żołnierzy, gdyż Szwedzi są skłonni znacznie zwiększyć swój kontyngent, w zależności od potrzeb szkoleniowych, czy też operacyjnych. Sztab NBG mieści się w Enköping w Szwecji natomiast kwatera operacyjna w Northwood w Wielkiej Brytanii (Battlegroup, 2010).

Charakterystyczną cechą zgrupowania nordyckiego jest system szkolenia nakierowany, głównie na specyficzne działania w ramach misji i operacji traktatowych. Szkolenie to przebiega na bazie tradycyjnej współpracy wojskowej. W zakresie dowodzenia i kontroli (C2), nordyckie ugrupowanie taktyczne chętnie wykorzystuje doświadczenia Wielkiej Brytanii, z którą państwa-uczestnicy utrzymują ścisłą współpracę wojskową. Liczą także na wsparcie Brytyjczyków w dziedzinie transportu strategicznego, szczególnie morskiego, w celu dyslokacji ludzi i ich wyposażenia. Sytuacja grupy nordyckiej jest specyficzna ze względu na status prawno-międzynarodowy jej uczestników. Szwecja i Finlandia, pragnąc pozostać państwami neutralnymi zastrzegają się, że ich uczestnictwo w działaniach reagowania kryzysowego może dotyczyć wyłącznie misji utrzymania pokoju i może to nastapić na wniosek ONZ lub OBWE. Specyficzny charakter skandynawskiej grupy bojowej wyraża się w tym, że w składzie grupy nordyckiej funkcjonuje Norwegia, która nie jest członkiem UE. Uczestnicy nordyccy porozumieli się, co do zasad zaangażowania i w przypadku, gdyby jeden z nich wycofał swoje siły to pozostałe państwa mogą zmodyfikować skład grupy nordyckiej i uzupełnić o komponenty niezbędne do działań operacyjnych. Wszystkie państwa zarezerwowały sobie prawo wycofania żołnierzy, w każdej chwili, z tym zastrzeżeniem, że całkowite rozwiązanie GB-1500 może nastąpić poprzez konsens uczestników i przy konsultacjach z Unią Europejską. O wyjątkowym charakterze grupy nordyckiej przesądza fakt, że głównymi uczestnikami są państwa neutralne; Finlandia, Irlandia i Szwecja, pozostałe dwa państwa; Estonia i Norwegia uczestniczą w NATO.

Ocenia się, że jest przygotowanych około 15 Grup Bojowych, które spełniają wymogi szkoleniowe i operacyjne, pełnią dyżury i mogą zostać przemieszczane w obszary objęte kryzysem. Jednakże, dotychczas żaden z takich oddziałów, w pełnym składzie nie brał udziału w operacji reagowania kryzysowego. Dotychczas, czyli bez mała dziesięć lat, od czasu sformułowania i zatwierdzenia koncepcji Grup Bojowych UE de facto, ta koncepcja nie znalazła odzwierciedlenia w praktyce. Pytanie, czy były okazje do wprowadzenia takich grup? Odpowiedź jest twierdząca. Grupy Bojowe mogły być skierowane do co najmniej trzech operacji, które Unia Europejska prowadziła w latach 2006-2014. Pierwsza misja to EUFOR - DR Kongo, latem 2006 r. Wówczas do działań powinna wkroczyć Grupa Bojowa dowodzona przez Niemców, gdyż wówczas RFN odpowiadała za dyżur bojowy. 27 grudnia 2005 r. Sekretarz ONZ zwrócił się do UE z prośbą o pomoc, w utrzymaniu pokoju w DR Kongo. Unia Europejska uznała, że jest zobowiązana do wspierania procesu transformacji w tym państwie. Zgodnie z wcześniejszymi ustaleniami dotyczącymi rotacji GB-1500 przypadała kolej na grupę dwunarodową francusko-niemiecką. W tej sytuacji, zgodnie z wcześniejszymi ustaleniami, Niemcy jako państwo ramowe miały zapewnić podstawowe elementy niezbędne do rozpoczęcia i realizacji działań, w tym: dowodzenie i finansowanie. W fazie przygotowawczej toczono spory dotyczące, zarówno uczestników, jak i sposobu przeprowadzenia operacji. 23 stycznia 2006 r., podczas szczytu francusko-niemieckiego, Angela 
Merkel odmówiła prezydentowi Jacques'owi Chiracowi skierowania do Konga francusko-niemieckiej Grupy Bojowej UE. Oprócz pani kanclerz, również minister obrony narodowej Franz Jung nie okazywał entuzjazmu dla kongijskiej wyprawy i mnożył przeszkody. Ogłosił pięć warunków, które należało spełnić, żeby Niemcy przejęli przywództwo misji: 1) zgoda rządu kongijskiego; 2) precyzyjny mandat Rady Bezpieczeństwa ONZ; 3) udział w misji innych członków UE, oprócz Francji i Niemiec; 4) koncentracja misji w stolicy DR Kongo - Kinszasie; limit czasowy - cztery miesiące. W związku z tymi przeszkodami oraz ze względu na duże zaangażowanie Niemiec na Półwyspie Bałkańskim oraz w Afganistanie, przyjęto formułę zbudowania ugrupowania taktycznego ad hoc. Fakt ten można uznać za pierwszą porażkę koncepcji Grup Bojowych UE (Ciupiński, 2013, s. 250).

W 2008 r. Szwecja, jako państwo ramowe ,nordyckiej” grupy bojowej, zaproponowała jej wykorzystanie w misji UE w Czadzie i Republice Środkowoafrykańskiej. Większość państw Unii nie poparła jednak tej inicjatywy. Została przeprowadzona operacja z wykorzystaniem wielonarodowej grupy ad hoc francusko-polsko-irlandzkiej (Pacek, 2010).

Praktycznym sprawdzianem dla grup bojowych na kontynencie europejskim mogła być druga faza operacji Althea w Bośni i Hercegowinie. Po reformie przeprowadzonej w lutym 2007 r., zadania wykonywało 2200 żołnierzy UE, czyli w świetle założeń wzmocniona grupa bojowa. Nie zdecydowano się skierować takiej grupy. Przyczyn może być kilka. Być może nie sformowano Grupy Bojowej BiH ze względu na fakt, że była to misja realizowana przy wsparciu ze strony NATO, w ramach porozumienia „Berlin plus”. Zgodnie z koncepcja GB-1500 powinny być one wykorzystane w warunkach dużej wymagalności z punktu widzenia warunków bojowych, a w Bośni i Hercegowinie nie trzeba było prowadzić walk, $\mathrm{z}$ użyciem sił zbrojnych.

Jako rzeczywista przyczyna powściaggliwości unijnych decydentów wobec ewentualnego skierowania dyżurującej grupy bojowej, podawany jest najczęściej argument, że dotychczas nie doszło do sytuacji, która odpowiadałaby przyjętym kryteriom i wymagałaby skierowania dyżurującej grupy bojowej (Antrpoius, 2006, s. 188). Ale takie podejście jest właściwie ucieczką od odpowiedzi. Przyczyn było znacznie więcej, chociaż sukces operacji Artemis był zasadniczym motywem dla sformułowania koncepcji grup bojowych, to ich praktyczny rozwój nie mógł w pełni odzwierciedlać modelu operacji z 2003 r. Wówczas, operacja została przeprowadzona siłami francuskimi, przy symbolicznym udziale innych państw członkowskich. Działania zostały „umiędzynarodowione", głównie ze względu na aspekty propagandowe. Do operacji zostały wykorzystane w pełni profesjonalne francuskie siły ekspedycyjne, które stacjonowały w Afryce i miały one bogate doświadczenie w prowadzeniu takich operacji. W związku z tym, udało się także złagodzić podstawowy niedostatek, w zakresie transportu strategicznego.

Wattpliwości dotyczące wiarygodności Grup Bojowych UE wystąpiły między innymi pod koniec 2008 r. Na początku grudnia, Sekretarz Generalny ONZ Ban Ki Moon poprosił o interwencję Unii Europejskiej w Demokratycznej Republice Konga. Ministrowie spraw zagranicznych rozpatrywali ten problem 8 grudnia 2008 r., na spotkaniu w Brukseli. Zastanawiano się przede wszystkim jak grzecznie odmówić (Ciupiński, 2013, s. 250). Z jednej strony, byłoby to niezgodne z zasadą multilateralizmu i pierwszy 
przypadek, że Unia Europejska odmówiła udziału w misji pokojowej, na zapotrzebowanie ONZ. Do takiej sytuacji nie chciał dopuścić minister spraw zagranicznych Francji Bernard Kouchner, ale rząd francuski także nie zajął wyraźnego stanowiska. Żadne z tzw. wielkich państw nie było w stanie przejać dowodzenia nad taką operacją. Wielka Brytania i Niemcy, w ogóle sprzeciwiali się zaangażowaniu, a ministrowie z pozostałych państw także nie przejawiali entuzjazmu. Nick Whitney, były dyrektor zarządzający Europejskiej Agencji Obrony, uznał, że jedną z przyczyn bezczynności Grup Bojowych - 1500 są absurdalne zasady finansowania. W ich świetle, to państwa kierujące swoich żołnierzy do operacji reagowania kryzysowego muszą, niemal w całości, pokrywać ponoszone koszty przynajmniej 90\% tzw. kosztów wojskowych (Ehler, 2010). Zasadniczym niedostatkiem i powodem unieruchomienia grup bojowych była niemożność skierowania ich do działań niespełniających kryteriów szybkiego reagowania (Terlikowski, 2010).

W 2009 r. podczas wrześniowego, nieformalnego spotkania ministrów obrony państw UE, Szwedzi zgłosili projekt modyfikacji Koncepcji Grup Bojowych UE, w kierunku ich większej elastyczności. W związku z tym, że niektóre państwa mają problemy z wypełnieniem kryteriów certyfikacji, zaproponowano, żeby pewne komponenty spełniały rolę rezerwy strategicznej, na przykład dla operacji aktualnie realizowanej, w Bośni i Hercegowinie, albo w Gruzji. Inną formą większej elastyczności mogło być wyłączenie najlepiej przygotowanych elementów do działań pierwszorzutowych: np. dowództw grup albo komandosów. Pozostałe pododdziały byłyby wówczas rezerwą. Propozycje nie spotkały się z jednoznacznie pozytywnym przyjęciem, gdyż widziano w nich nierówne traktowanie partnerów i mówiono o „Grupach Bojowych dwóch prędkości” (Gros-Verheyde, 2009). Rada UE w konkluzjach nt. WPBiO z 17 listopada 2009 r. wskazała, że użycie grup w tego rodzaju operacjach byłoby możliwe tylko w wyjątkowych sytuacjach, ocenianych osobno i wymagających uzyskania każdorazowo jednomyślnej zgody w UE.

Do sprawy efektywności jednostek interwencyjnych powrócono rok później. Według parlamentarnego raportu należało zweryfikować koncepcje Grup Bojowych UE. Proponowano, żeby oprócz grup, przygotowanych według dotychczasowych standardów, dopuścić możliwość wykorzystania grupy niszowej lub hybrydowej, czyli cywilno-wojskowej. Stworzyłoby to możliwość skierowania takich grup do realizacji zadań, w konfliktach niskiej intensywności. Należy zweryfikować także system finansowania grup, w myśl propozycji polskiej prezydencji. Zgłaszano również projekty utworzenia stałych grup bojowych, finansowanych ze środków unijnych. Caroline Henrion twierdzi, że Europa jest bardzo daleka od osiagnięcia skutecznych zdolności reagowania kryzysowego. Ażeby to zmienić, należy Grupy Bojowe UE wyłączyć z procedur jednomyślnego podejmowania decyzji o skierowaniu ich do działań (Henrion, 2010).

W związku z zapytaniami dlaczego GB UE pełnią ,puste” dyżury poszukiwano odpowiedzi w sferze pozamilitarnej. W 2010 r., przy okazji nieformalnego spotkania ministrów obrony, w Gandawie, minister obrony Austrii poddał pod rozwagę wykorzystanie unijnych jednostek szybkiego reagowania, w sytuacjach klęsk żywiołowych. Również podczas polskiego przewodnictwa w Radzie UE, w drugiej połowie $2011 \mathrm{r}$. Polacy zgłosili szereg wniosków mających sprzyjać podejmowaniu decyzji dotyczących wykorzystania europejskich sił interwencyjnych. Najważniejsze z tych propo- 
zycji dotyczyły: powołania „,kwatery głównej UE”, stałych lub „w połowie stałych” Grup Bojowych UE oraz zmiany zasad finansowania wydatków na cele wojskowe. Dla niektórych rozwiązań uzyskano wsparcie Francji, Niemiec, Hiszpanii i Włoch, natomiast głównym oponentem była Wielka Brytania (Ciupiński, 2012, s. 84-89). W sprawie zmiany koncepcji wykorzystania Grup Bojowych ministrowie spraw zagranicznych i obrony porozumieli się podczas posiedzenia Rady 12 listopada 2012 r. Dopuszczono możliwość wykorzystania jednostek interwencyjnych poza standardową procedura generacji sił, np. w razie konieczności przeprowadzenia tzw. operacji pomostowej; zalecono bardziej elastyczne planowanie. Sugerowano także debatę nad poszukiwaniem bardziej racjonalnego finansowania Grup Bojowych (Council, 2012, s. 19).

$\mathrm{Na}$ arenie międzynarodowej UE jest zatem aktorem, do którego z powodzeniem znajduje zastosowanie koncepcja tzw. mocarstwa niewojskowego (civilian power). Mocarstwo takie oddziałuje na otoczenie międzynarodowe, używając głównie środków gospodarczych, finansowych i politycznych, a nie potęgi militarnej. Do jego cech zalicza się m.in. odżegnywanie się od stosowania presji wojskowej na rzecz środków pokojowych, nadrzędność działań politycznych i dyplomatycznych w rozwiązywaniu problemów światowych oraz wykorzystywanie do tego celu mechanizmów i struktur organizacji międzynarodowych (Milczarek, Zajączkowski, 2014, s. 173). Autorzy tego słusznego spostrzeżenia nie oparli się sugestywnym skojarzeniom Unii Europejskiej jako „gospodarczego giganta i politycznego karła”. Ale, nie szczędzono UE jeszcze bardziej pogardliwych określeń, jak na przykład „militarny robak”, a jej aktywność międzynarodową nazywano „dyplomacją czekową” (Goyet, Edwards, 2005, s. 39-63). Liczono na to, że nowe regulacje traktatowe, czyli klauzula solidarności i formuła wzmocnionej współpracy, spowodują przyspieszenie w konsolidacji WPBiO. Przyspieszenie jednak nie nastąpiło, chociażby ze względu na zrozumiały okres transformacji i budowy nowych struktur. W tym okresie niektórzy eksperci zarzucali pani Ashton, że interesuje się głównie problemami dyplomacji i budową Europejskiej Służby Działań Zewnętrznych, zaniedbując sferę bezpieczeństwa i obrony.

Istotnym powodem spowolnienia w pozyskiwaniu zdolności wojskowych i cywilnych WPBiO był światowy kryzys finansowy, który poważnie osłabił strefę euro i wymógł poszukiwanie oszczędności. W Europie rozpoczęła się kolejna faza „wyciągania korzyści z pokoju", co wyrażało się w redukcjach wydatków obronnych we wszystkich państwach UE. Trzecim powodem osłabienia dynamiki rozwoju europejskiej autonomii strategicznej był wyraźny zanik czynników motywacyjnych. Francja, która dotychczas było orędowniczką uniezależnienia Europy Zachodniej od pomocy wojskowej USA, zweryfikowała swoje stanowisko, przestała wskazywać WPBiO UE, jako alternatywę dla NATO. Przy okazji jubileuszu 60-lecia NATO, w kwietniu 2009 r., Francja powróciła do struktur wojskowych Sojuszu i włączyła się w główny nurt jego działań, np. kierując swoich żołnierzy do Afganistanu, w ramach ISAF. Wydaje się, że Francuzi powątpiewali w możliwość przeprowadzenia skutecznej operacji wojskowej przy użyciu grupy wielonarodowej, o czym świadczy fakt samodzielnego przeprowadzenia operacji antyterrorystycznej w Mali, w pierwszej połowie $2013 \mathrm{r}$. W tym czasie dyżur pełniła Weimarska Grupa Bojowa, pod polskim dowództwem.

W 2014 r. idea grup poniosła kolejną porażkę w konfrontacji z kryzysem w Republice Środkowej Afryki. Doszło do ludobójstwa i większość ministrów spraw zagranicz- 
nych poparła francuski projekt skierowania tam GB UE. Sytuacja spełniała wszelkie wymogi przewidziane w „Koncepcji Grup Bojowych Unii Europejskiej”. Jednakże, zdecydowany sprzeciw zgłosiła Wielka Brytania. Również w przypadku tego kryzysu zorganizowano i skierowano do Afryki siły zbudowane przez „koalicję chętnych” (Gros-Verheyde, 2014).

\section{Udział Polski w rozwoju zdolności wojskowych Unii Europejskiej}

W trakcie negocjacji akcesyjnych polscy politycy pozytywnie oceniali cele realizowanej przez UE Wspólnej Polityki Zagranicznej i Bezpieczeństwa, ale początkowo z rezerwą traktowano projekty wchodzące w zakres Europejskiej Polityki Bezpieczeństwa i Obrony. Jeden z postulatów polskich polityków dotyczył włączenia przedstawicieli państw kandydujących do procesu decyzyjnego. Państwa Piętnastki zignorowały ten postulat, co miało wpływ na polskie zaangażowanie w budowę potencjału wojskowego w ramach EPBiO.

Po uzyskaniu statusu Państwa Członkowskiego, Polska bardzo aktywnie włączyła się w realizację Europejskiego Celu Zasadniczego/Operacyjnego - 2010, akcentując zainteresowanie Grupami Bojowym UE. Pierwsze trzynaście takich grup zostało zgłoszonych 22 listopada 2004 r. Polska była wśród państw, które przejęły na siebie obowiązek dowodzenia w grupie wielonarodowej, jako państwo wiodące. 13 listopada 2006 r. podczas kolejnego spotkania ministrów obrony przedstawiciele zainteresowanych państwa podpisali Porozumienie Ogólne dotyczące Ramowych Regulacji dla Grupy Bojowej Unii Europejskiej. Na tej podstawie została utworzona niemiecko-łotewsko-litewsko-polsko-słowacka grupa bojowa. Początkowo umownie jednostkę nazywano „grupą wschodnią”, a później „grupą centralną”.

Ze strony Polski do realizacji zadań w wielonarodowej Grupie Bojowej został wytypowany Batalion z Międzyrzecza o stanie osobowym 800 żołnierzy, w pełni sprofesjonalizowany. Dysponuje on 160 pojazdami, w tym 53 KTO Rosomak. Pododdział nabył doświadczeń w misjach w Afganistanie i Iraku, a jego żołnierze mają bardzo dobrą opinię. Po relatywnie długich negocjacjach i technicznych ustaleniach wkłady poszczególnych partnerów wynosiły w przybliżeniu: Polska $-50 \%$, RFN $-30 \%$, Słowacja $-10 \%$, Litwa $-5 \%$, Łotwa $-5 \%$. Dowództwo Operacyjne zlokalizowano w Poczdamie. W listopadzie 2009 r. Grupa Bojowa przechodziła ostatnią fazę certyfikacji, przy okazji ćwiczeń pod kryptonimem „Common Challenge 09”. Założeniem ćwiczeń było stworzenie warunków bezpieczeństwa dla przeprowadzenia demokratycznych wyborów do parlamentu ustawodawczego, w fikcyjnym kraju o nazwie Alisia. Miejscem ćwiczeń był Poznań i Wędrzyn, a w ćwiczeniu brali głównie udział żołnierze 17 Brygady Wielkopolskiej. Pełną zdolność operacyjną Wschodnia/Centralna Grupa Bojowa uzyskała w pierwszym półroczu 2010 roku i przejęła dyżur, zgodnie z wcześniej zatwierdzonym planem, 1 lipca $2010 \mathrm{r}$. W tym półroczu nie doszło do żadnych konfliktów, ani kryzysów, do których potrzebna byłaby interwencja wojskowa.

W politycznych i wojskowych kręgach polskiego rządu i parlamentu koncepcja Grup Bojowych cieszyła się powodzeniem i poparciem, szczególnie ze strony ówczesnego ministra obrony narodowej Radosława Sikorskiego, osobiście zaangażowanego 
w zainicjowanie kolejnych dwóch Grup Bojowych, w których Polska miała być krajem wiodącym. Uznano, że wspólna działalność wojskowa skonsoliduje i ożywi współpracę Trójkąta Weimarskiego. 25 lipca 2006 r. na spotkaniu, w Wieliczce ministrowie obrony Polski, Niemiec i Francji zdecydowali o utworzeniu Europejskiej Grupy Bojowej w formacie „Trójkąta Weimarskiego”. W dniu 7 grudnia 2006 r. szefowie sztabów trzech państw ustalili, że Weimarska Grupa Bojowa UE (UE Weimar Battlegroup) będzie gotowa do objęcia dyżuru w pierwszej połowie 2013 roku. $Z$ oficjalnym podpisaniem porozumienia oczekiwano do początku polskiej prezydencji w Radzie UE i uroczystość miała miejsce 5 lipca 2011 r. Uzgodniono, że państwem wiodącym będzie Polska, która dostarczy główną siłę bojową w postaci batalionu zmechanizowanego z 17 Brygady. Dowodzenie powierzono polskiemu generałowi, ale dowództwo operacyjne zlokalizowano w Mont Valerien. To stanowiło główny wkład Francuzów, którzy oprócz dowództwa dostarczali wsparcia medycznego. Niemcy zapewniali wsparcie logistyczne. Do momentu uzyskania zdolności bojowych, a następnie podczas pełnienia dyżuru pracowała grupa koordynacyjna, odpowiedzialna za zarządzanie środkami. BGW, oprócz zadań wykonywanych w ramach zaakceptowanej przez Radę Koncepcji Grup Bojowych UE, miała stwarzać możliwość poszukiwania nowych metod doskonalenia tej koncepcji. Podstawowe założenie eksperymentu dotyczyło ustanowienia stałych zasobów zdolności (permanent capability pool) lub w skromniejszym wariancie częściowo, lub w połowie stałych (semi-permanent) komponentów grup bojowych, głównie o charakterze cywilnym; elementy wsparcia logistycznego i medycznego. Częściowo stały charakter powinien mieć system dowodzenia. Takie rozwiązanie sprzyjałoby elastyczności wykorzystania grupy, lub jej części w operacjach reagowania kryzysowego, zarówno o charakterze wojskowym jak też cywilnym. W trakcie pełnienia dyżuru przez Weimarską Grupę Bojową Francja podjęła, w Mali operację bojową przeciwko separatystom i terrorystom, ale dyżurująca jednostka trójnarodowa nie została w tej operacji wykorzystana.

W styczniu 2007 r. szefowie sztabów Polski, Czech, Słowacji i Węgier porozumieli się, żeby utworzyć kolejną grupę regionalną, w której Polska także ma odgrywać rolę państwa wiodącego. Rozważano włączenie do grupy komponentów z Ukrainy, za czym przemawiały względy natury geostrategicznej i euroatlantyckie aspiracje ówczesnych władz Ukrainy. Nie doszło do realizacji tej idei, co nie przeszkodziło w kontynuowaniu prac nad sformowaniem grupy. W październiku 2009 r. doszło do spotkania ministrów obrony Grupy Wyszehradzkiej i na tym spotkaniu podjęto decyzję o sformowaniu wspólnej Grupy Bojowej UE. Przesłanek dla takiego przedsięwzięcia było kilka. Historycznie rzecz ujmując, to zasadniczym motywem powołania grupy była integracja dla bezpieczeństwa. Już dziesięć lat wcześniej Polacy wspólnie ze Słowakami próbowali utworzyć wspólną brygadę reagowania kryzysowego, zapraszając do niej także Ukraińców. Polska i Słowacja wyniosły już doświadczenia ze wspólnej GB-1500 UE, która przeszła proces szkolenia i certyfikacji i zdążyła odbyć dyżur w 2010 r. (Tarasovič, 2011, s. 71).

Niezależnie od zaangażowania w rozwój zdolności wojskowych, w ramach Europejskiego Celu Operacyjnego - 2010, Polacy angażowali się w realizację bieżących zadań reagowania kryzysowego. Uczestniczyli w operacjach wojskowych: od $2004 \mathrm{r}$. w operacji w Bośni i Hercegowinie - Althea i w 2006 r. w operacji EUFOR DR Kongo 
(Major 2010, s. 311). Najliczniejszy polski kontyngent wojskowy został skierowany do EUFOR Czad/RSA w sile 400 żołnierzy, funkcjonariuszy i pracowników wojska, w okresie od 1 lutego 2008 r. do 30 stycznia 2009 roku. Misja w Czadzie wypełniła spoczywające na niej zadania mandatowe bez poważniejszych incydentów, ofiar i strat. Polska, jako największe państwo spośród 12 nowych członków UE wniosła też największy potencjał wojskowy, sporo doświadczenia w operacjach pokojowych i stabilizacyjnych. W analizie przeprowadzonej na zlecenie Zgromadzenia Parlamentarnego UZE/UE oceniono, że poziom przygotowania polskich żołnierzy do operacji zewnętrznych oraz procedury ich obowiązujące w niczym nie odbiegają od europejskich standardów. Podkreślano dobre morale żołnierzy kierowanych do operacji (Henderson, 2007, s. 5-6).

Należy stwierdzić, ze kulminacja polskiego zaangażowania w rozwój Wspólnej Polityki Bezpieczenstwa i Obrony przypadała na okres poprzedzający przyjęcie przewodnictwa w Radzie UE oraz w trakcie jej trwania. Rezultaty wysiłków nie były imponujące i polscy politycy mogli być rozczarowani małym wsparciem dla tych wysiłków ze strony najbliższych partnerów zarówno ze strony Grupy Weimarskiej, jak też Grupy Wyszehradzkiej. Nie zostały uwzględnione postulaty Polski dotyczące bardziej wszechstronnego wykorzystania Grup Bojowych UE, jak też nie zmieniono zasad ich finansowania. Polscy politycy i eksperci sugerowali także uaktualnienie Europejskiej Strategii Bezpieczeństwa. Liczono na szczyt w grudniu 2013 r., ale sprawy zdolności obronnych ponownie zostały odłożone w bliżej nieokreśloną przyszłość. Rada Europejska ograniczyła się do opublikowania ogólnego komunikatu o charakterze postulatywnym: „UE i jej państwa członkowskie muszą być w stanie szybko i skutecznie planować i rozmieszczać odpowiednie zasoby cywilne i wojskowe. Rada Europejska podkreśla potrzebę poprawy unijnych zdolności do szybkiego reagowania, między innymi za pośrednictwem bardziej elastycznych i łatwiejszych do rozmieszczania grup bojowych UE zgodnie z tym, co postanowią państwa członkowskie. Należy bezzwłocznie przeanalizować aspekty finansowe misji i operacji UE, również w kontekście przeglądu mechanizmu Athena, z myślą o udoskonaleniu systemu finansowania tych misji i operacji, na podstawie sprawozdania Wysokiego Przedstawiciela" (Konkluzje, 2013).

Polacy i państwa bałtyckie były rozczarowane zlekceważeniem zagrożeń za wschodnią granicą Unii Europejskiej. Mało prawdopodobne jest zaangażowanie Grupy Bojowej UE w stabilizowanie sytuacji na Ukrainie. Decyzja musiałaby zapaść jednogłośnie, a dla takiego pomysłu nie uda się przekonać nie tylko państw śródziemnomorskich, ale nawet najbliższych partnerów: Czechów, Niemców, Słowaków i Wegrów. Dlatego w pełni uzasadnione jest skoncentrowanie się na wzmocnieniu narodowych zdolności obronnych. Taką postawę demonstrują polscy politycy nie tyko na forum Unii Europejskiej. Prezydent Bronisław Komorowski powiedział: „Zdecydowanie odchodzimy od nadgorliwie, nieopatrznie ogłoszonej w 2007 roku polityki ekspedycyjnej. Koniec łatwej polityki, łatwego wysyłania żołnierzy polskich na antypody świata" (Prezydent, 2013). W Unii Europejskiej trudno znaleźć państwa skłonne do skierowania żołnierzy w rejony objęte kryzysami w Afryce lub Azji. Sądzę, że jeżeli dojdzie do zaangażowania sił wojskowych w obronie wolności i demokracji w Europie, to bardziej prawdopodobne jest wykorzystanie Sił Odpowiedzi NATO, niż Grup Bojowych Unii Europejskiej. 


\section{Bibliografia}

Antrpoius A., Deschaux-Beaume D. (2006), La PESD et ses évolutions, Bruxelles.

Background Note - Capability Development Plan, European Defence Agency, 8 July 2008.

Barcik J. (2007), Europejska Polityka Bezpieczeństwa i Obrony, Wydawnictwo Brandta.

Ciupiński A. (2012), Polska prezydencja wobec rozwoju Wspólnej Polityki Bezpieczeństwa i Obrony, w: Polska prezydencja wobec wyzwań współczesnej Unii Europejskiej, red. A. Legucka, Warszawa.

Ciupiński A. (2013), Wspólna Polityka Bezpieczeństwa i Obrony Unii Europejskiej. Geneza. Rozwój. Funkcjonowanie, Difin, Warszawa.

Cloos J. (2007), EU-UN co-operation on crisis management, „European Security and Defence Policy", January, Issue 3.

Dumoulin A., Mathieu R., Sarlet G. (2003), La Politique Européenne de Sécurité et de Défense (PESD) de l'Opèratoire à l'Identitaire. Genesè, Structuration, Ambitions, Limites, Brussels.

Edwards G. (2005), The Pattern of the EU's Global Activity, w: International Relations and the European Union, red. Ch. Hill, M. Smith, Oxford University Press.

Ehler C. (2010), Rapport sur la coopération civilo-militaire et le développement des capacités civilo-militaires, PE(2010/2071(INI)) 5 novembre.

EU Battlegroups, EU Council Secretariat Factsheet, Brusseles, February 2007, Full Operational Capability 2007, http://www.consilium.europa.eu, 9.02.2013.

The EU Battlegroup Concept and the Nordic Battlegroup, http://www.sweden.gov.se/sb/d/9133/ a/82276, 9.02.2013.

Gagor F. (2008), Polskie doświadczenia wyniesione z operacji wojskowych i ich wpływ na transformację sit zbrojnych RP, „Zeszyty Naukowe AON”, nr 1(70).

Gliere C. (red.) (2007), European security and defence: Core documents 2007, ISS EU, „Chaillot Paper" Paris, vol. VIII.

Glière C. (2009), Sécurité et défense de l'UE Textes fondamentaux 2008, „Cahier de Chaillot”, vol. IX Paris.

Goyet C., L'UE comme puissance militaire?, „Nouvelle Europe”, http://www.nouvelle-europe.eu/ node/1526, 12.09.2014.

Gros-Verheyde N., L'idée suédoise de modulation des battlegroups, http://www.bruxelles2.eu/defense-ue/capacites-milit-\%E2\%80\%93-exercices-ue/lideesuedoisedemodulationdesbattlegroups.html, 9.02.2013.

Gros-Verheyde N., Battlegroup pour la Centrafrique? Comment Cathy a dit stop!, http://www.bruxelles2.eu/zones/tchad-soudan/battlegroup-pour-le-centrafrique-et-la-haute-representante-mis-le-hola.html, 5.10.2014.

Groupements-tactiques-1500-5eme, http://www.france-allemagne.fr, 14.01.2010.

Haine J. Y. (red.) (2003), De Laeken à Copenhague - Les textes fondamentaux de la défense européenne, „Cahier de Chaillot”, vol. III, Paris.

Henderson M. D., Les forces terrestres européennes dans les opérations extérieures: personnels et financement. Contributions allemande et polonaise, Assemblée de l'Union.

Henrion C., Les groupements tactiques de l'Union européenne, http://www.grip.org/fr/siteweb/images/NOTES_ANALYSE/2010/NA_2010-01-18_FR_C-HENRION.pdf, 9.02.2013.

Kuźniar R. (2005), Polityka i siła. Studia Strategiczne. Zarys problematyki, Wydawnictwo Scholar, Warszawa.

Major C. (2010), EUFOR RD Congo, w: European Security and Defence Policy. THE FIRST 10 YEARS (1999-2009), Paris. 
Milczarek D., Zajączkowski K. (2014), Unia Europejska we współczesnym świecie; olbrzym gospodarczy, polityczny karzet?, w: K. Wojtaszczyk, M. Mizerska-Wrotkowska, W. Jakubowski, Polska w procesie integracji europejskiej. Dekada doświadczeń (2004-2014), Warszawa.

Pacek B. (2010), Operacje wojskowe Unii Europejskiej na przyktadzie EUFOR TCHAD RCA, Wydawnictwo AON, Warszawa.

Prezydent, http://www.prezydent.pl/aktualnosci/wydarzenia/art,2652,prezydent-koniec-polityki-ekspedycyjnej.html, 15.08.2013.

Rezolucja Parlamentu Europejskiego z dnia 10 marca 2010 r. w sprawie wdrażania europejskiej strategii bezpieczeństwa oraz wspólnej polityki bezpieczeństwa i obrony (2009/2198 (INI)).

Simón L. (2010), Command and control? Planning for Eu military operations, „Occasional Paper” 81 , Paris, January.

Słomczyńska I. (2007), Europejska Polityka Bezpieczeństwa i Obrony, UMCS, Lublin.

Tarasovič V. (2011), The possibilities for cooperation of the Visegrad countries and their Eastern Neighbours in the development of security and defence policy in the EU and beyond: the Slovakian perspective, w: Visegrad cooperation within NATO and CSDP, Visehrad Fund V4 Papers, PISM, nr 2, s. 71.

Terlikowski M. (2010), Grupa bojowa Unii Europejskiej pod polskim dowództwem, „Biuletyn PISM", nr 3 (611), 11 stycznia.

Wei-Fang Ch. (2012), National Interests vs. Security and Defense Integration in the EU: A comparative case study of Britain and Germany, Durham University.

Zięba R. (2000), Europejska Tożsamość Bezpieczeństwa i Obrony, Wydawnictwo Scholar, Warszawa.

Zięba R. (2005), Europejska Polityka Bezpieczeństwa i Obrony, Wydawnictwo Sejmowe, Warszawa.

Zięba R. (2007), Wspólna Polityka Zagraniczna i Bezpieczeństwa Unii Europejskiej, Wydawnictwo Akademickie i Profesjonalne, Warszawa.

\section{Streszczenie}

Artykuł dotyczy rozwoju polityki bezpieczeństwa Unii Europejskiej, od chwili jej powstania do 2014 r. W ramach tej polityki próbowano także pozyskać zdolności wojskowe, niezbędne do zbudowania systemu reagowania kryzysowego. Dokonywało się to na zasadzie pełnej dobrowolności, a w związku z tym wszystkie Państwa Członkowskie UE kierowały się głównie interesami narodowymi. W ramach Europejskiej Polityki Bezpieczeństwa i Obrony, przemianowanej w Traktacie lizbońskim na Wspólną Politykę Bezpieczeństwa i Obrony Unii Europejskiej, zrealizowano dwa tzw. Cele Zasadnicze/Operacyjne. Pierwszy z nich został ogłoszony w grudniu 1999 r. w Helsinkach i zrealizowany do końca 2003. Europejski Cel Zasadniczy/Operacyjny 2010 miał na celu doskonalenie zdolności wojskowych, w tym zbudowanie sił szybkiego reagowania pod nazwą Grup Bojowych UE. Zorganizowano i przeszkolono ok. 15 takich jednostek, ale dotychczas żadna z nich nie została skierowana do działań w rejonie kryzysu. Polska należy do aktywnych uczestników WPBiO UE i dotychczas zorganizowała trzy grupy bojowe o składzie wielonarodowym. Dwie spośród nich pełniły dyżury 2010 r. i 2013 r. Kolejna grupa pod polskim dowództwem jest przewidziana w harmonogramie dyżurów na rok $2016 \mathrm{r}$., ale mało prawdopodobne jest wykorzystanie jej do realnych działań. Temat zdolności wojskowych nie należy do priorytetowych zadań Unii Europejskiej.

Słowa kluczowe: grupy bojowe, integracja wojskowa Unii Europejskiej, cywilne i wojskowe operacje 
The military capacity of the European Union. The prospects for battle groups

\section{Summary}

The paper concerns the development of the European Union's security policy, from its beginnings to 2014. The framework of this policy also served the purpose of developing the military capacities that are necessary to establish an emergency response system. The principle of totally voluntary participation has always operated in this respect, therefore all EU member states have mainly been concerned with their national interests. Under the European Security and Defence Policy (ESDF), renamed in the Lisbon Treaty as the Common Security and Defence Policy (CSDP) for the European Union, two Headline Goals have been achieved. One was announced in Helsinki, in 1999, and achieved by the end of 2003. The European Headline Goal 2010 involved the improvement of military capability, including rapid response forces, named EU Battle Groups. Around fifteen units have been organised and trained, none of which, however, has been deployed in a crisis region so far. Poland is among the active participants of the CSDP and has organised three multinational battle groups. Two of them were on duty in 2010 and 2013. Another group under Polish command is scheduled to be on duty in 2016, but it is not likely to participate in real action. The issue of military capability is not a priority for the European Union.

Key words: battle groups, European Union military integration, civil and military operations 